\title{
Rosas y lirios para María. Una antífona pintada*
}

\author{
Giovanni Pozzi \\ Universidad de Friburgo
}

Título: Rosas y lirios para María. Una antífona pintada.

Resumen: El presente artículo analiza la simbología cristológico-mariana y los valores cifrados de una naturaleza muerta de carácter floral datada en el primer tercio del siglo XVII.

Palabras clave: Literatura y pintura, iconología, bodegón, barroco, simbología cristológico-mariana.

Fecha de recepción: 2/1/2013.

Fecha de aceptación: 24/1/2013.
Title: Roses and Lilies for Maria. A Painted Antiphone.

Abstract: This paper focuses upon the Christology and Marian symbols and the hidden notes of a "bodegón" of flowers (c. XVII Century: 1620-1640).

Key words: Literature and Painting, Iconology, "bodegón", Baroque, Christology and Marian symbols.

Date of Approval: 24/1/2013.

EN TORNO A UNA NATURALEZA MUERTA. UN ABANICO DE INTERPRETACIONES

Repitiendo en 1985 la tradicional cita de otoño en torno a las tablas lujosamente ornadas de exquisiteces naturales en pose, la galería Lorenzelli de 


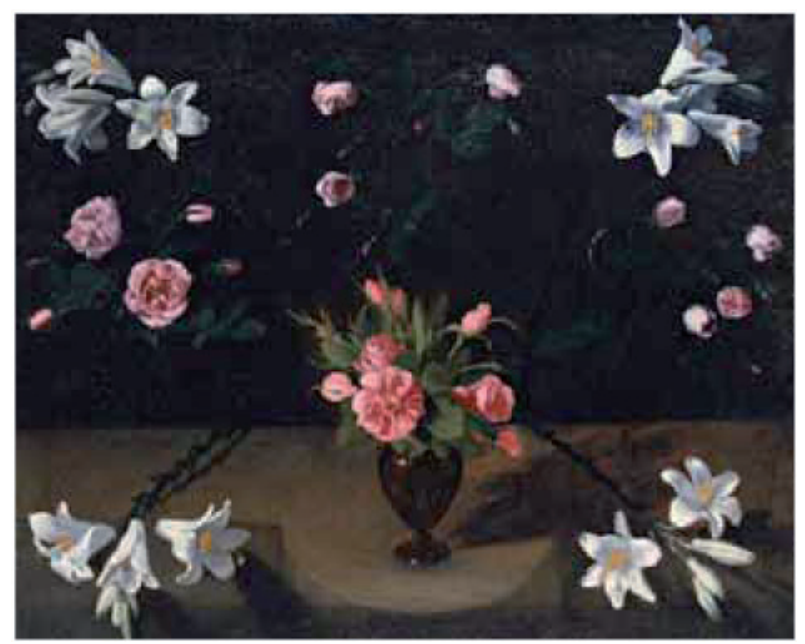

Bérgamo convidó a nueve expertos a degustar la gracia de una composición tan singular que no encuentra parangón en su género ${ }^{1}$.

Sobre una repisa de piedra gris, rematado por la mitad en semicírculo, reposa un jarrón negro que contiene un ramo de nueve rosas rojas. Lo rodean cuatro varas de lirio, dos que descansan sobre la mesa y dos que se alzan al fondo, con cinco flores cada una. De la parte trasera emergen también tres tallos de rosas, con seis, ocho, nueve flores, unas por abrir y otras abiertas.

Las interpretaciones del tema ofrecidas por los invitados convergen sobre el hecho de que el cuadro desarrolla un asunto simbólico. La disposición singular de los objetos retratados solo deja perplejo a Gombrich, pero la suya es una cautela de orden general contra la

* El artículo original, "Rose e gigli per Maria. Un'antifona dipinta”, está recogido en Giovanni Pozzi, Sull'orlo del visibile parlare, Milano, Adelphi, 1993, pp. 185-213. Traducción de Rafael Bonilla Cerezo (Universidad de Córdoba). Regalo esta traducción a María J. Moreno Prieto.

1 Las intervenciones se recogen en el catálogo Forma vera. Contributi a una storia della natura morta italiana, a cura di Pietro Lorenzelli e Alberto Veca, Bergamo, 1985, pp. 203-29. Los nombres de los expertos, en el orden en que comparecen: Ingvar Bergström, Ferdinando Bologna, Ernst Hans Gombrich, Mina Gregori, Marino Marini, Sam Segal, Federico Zeri, Giovanni Testori, Marco Rosci. Los precede la invitación de Pietro Lorenzelli, con una nota ilustrativa del cuadro, de cual se reproducen el marco original, el dorso y el frontal en las pp. 198-201. 
imperante moda que no ve higo o manzana sin asociarlos al pecado original $^{2}$. Convergen también sobre el simbolismo cristológicomariano, con algunas reservas de Bologna a favor de un destino nupcial. Pero afloran divergencias en la individuación de los contenidos. He aquí un esquema:

\section{Rosas y lirios son simbolos marianos:}

a) de la persona completa: Bergström, Segal, Zeri.

b) remiten a las letanías lauretanas: Bologna, Marini.

c) al rosario: Bologna, Marini.

d) a la anunciación: Bologna, Gombrich, Marini, Segal.

e) a la dormición y asunción: Zeri.

f) a la maternidad y virginidad: Bologna.

g) a la inmaculada concepción: Bologna, Marini, Segal.

h) a la inocencia: Gombrich.

i) a la pureza: Zeri.

j) a la belleza: Zeri.

k) al hortus conclusus: Bergström, Gregori.

2. Son simbolos cristológicos:

a) Cristo en la pasión: Marini, Segal.

b) en la vida y en las obras: Segal.

3. Son simbolo secular de belleza femenina: Bologna.

4. Son simbolos esotéricos:

a) de un implícito analismo atávico: Marini.

2 Crisol de testimonios contradictorios es la disputa en torno al punto de los eventuales valores simbólicos ligados a naturalezas muertas de aspecto naturalista. Emergen de modo significativo del monumental Natura in posa. La grande stagione della natura morta europea, a cura di Ingvar Bergström, Claus Grimm, Marco Rosci, Michel e Fabrice Faré, Juan Antonio Gaya Nuño, Milano, Rizzoli, 1977, cuya amplia bibliografía es actualizada en el catálogo de Bérgamo y en el de la exposición del Prado, Pintura española de bodegones y flores, ed. Alfonso Pérez Sánchez, Madrid, Museo del Prado, 1983; aquí con particular claridad el autor de la introducción valora los límites del empleo sagrado admitido por el género (15-17). 
b) de un aura heterodoxa, esotérica: Rosci.

Además de a las flores, se atribuye un significado simbólico

1. al jarrón: en sentido sagrado, por Marini ("Virgen-Jarrón recipiente purísimo del Niño”) y por Rosci (la píxide); esotérico, por Rosci (el Grial).

2. a la mesa: en cuanto que evoca el altar o el trono de la Virgen, por Gregori, Marini, Zeri.

En cuanto a la naturaleza del lenguaje icónico, Gregori habla de exvoto, Marini de exemplum y encomio figurado, Gregori y Marini de emblema, y este último cita también el enigma y el mote (suponiendo por ello una alusión a la empresa). Algunos textos bíblicos (Marini, Segal, Testori), patrísticos (Segal), hagiográficos (Zeri) y de poesía secular (Bologna, Zeri) se citan como apoyo de las varias interpretaciones; pero nadie conjetura que el cuadro pueda transmitir un mensaje puntual según las reglas precisas entonces en auge.

Virginidad, maternidad, inmaculada concepción, inocencia, pureza, belleza son los atributos marianos evocados, por separado o en grupos. No son, teológicamente hablando, conceptos análogos. La óptica teológica, que no deja de contar en un tema sacro, plantea más bien alternativas que no equivalencias. Son algunos entre los muchos atributos de María que la especulación y la práctica devota han cubierto con una simbología inmensa pero a la vez puntual. Todo el progreso de la piedad y de la teología se ha acumulado sobre ellos. Nuevas fiestas, nuevas devociones, nuevos dogmas han inducido nuevos conceptos sin alterar jamás el aparato metafórico adquirido. Cuando se afirma la creencia en la inmaculada, el lirio, antes destinado a significar la virginidad, la castidad, la inocencia de la virgen, es llamado a representar también (y sobre todo) este nuevo dato.

Sin embargo, la polisemia de esta entidad metafórica, en apariencia ilimitada y recargada sin tregua, conservaba su riguroso orden interno, por el cual se respetaban la diferencia y la jerarquía de los postulados dogmáticos, morales y anagógicos cubiertos por un solo figurante metafórico. Había un orden de los significados. Se nota con mucha claridad precisamente en el caso del lirio y la rosa, constatando que los muchos significados se distribuyen en una serie de parejas opuestas. Si el lirio significa la virginidad, o 
sea, un aspecto de la singular posición de María en tanto que mujer, a él se opone en la rosa la maternidad. Si la inocencia, prerrogativa conexa a su persona humana y consistente en la exención del pecado actual, se le opone la paciencia como sumisión a los efectos del pecado. Si la castidad, virtud moral que comporta la abstención del placer sexual, se le opone la caridad entendida como amor no carnal. Si la virginidad, entendida como categoría de santidad, se le opone el martirio, sufrido espiritualmente por la madre en la Pasión del hijo. Solo la inmaculada concepción no tiene correlato; pero se tiende a dárselo atribuyendo a la rosa el significado de maternidad. Es una correlación aceptable en cuanto que la maternidad es la razón sobre la que se funda el dogma. La ampliación de las valencias semánticas bajo un único significante responde a un sistema de correspondencias entre los significados expresados por los dos símbolos. El uno puede ser nombrado sin el otro, pero en el nivel paradigmático el uno se contrapone al otro. La presencia coetánea del lirio y la rosa en nuestro cuadro sugiere por ello una co-presencia de dos significantes opuestos. Pero también la duplicación de la rosa, en las guirnaldas y en el ramo, postula probablemente un desdoblamiento del significado conexo con la rosa: un correlato lo expresan los lirios de las guirnaldas, el otro es conferido al ramo central.

\section{TEOLOGÍA SIMBÓLICA Y GLOSARIOS MARIANOS}

La consulta de este aparato simbólico y la valoración de las relativas correspondencias son soberbiamente facilitadas y satisfechas por una florida producción de repertorios que se multiplica en la edad a la que se remonta el cuadro, comenzando por el impresionante cómputo de Hipólito Marracci que reúne junto a las relativas fuentes más de dos mil títulos marianos con el criterio alfabético de la enciclopedia ${ }^{3}$. Ya antes, en 1639, Teófilo Raynaud había seleccionado severamente los atributos aprobados por la más sólida teología, con un precioso aparato de referencias ${ }^{4}$. Al mismo tiempo que Marracci, ofrece un suntuoso ensayo de "botanique

3 Polyanthea mariana... qua deiparae virginis Mariae nomina et selectiora encomia ex ss. patrum... monumentis collecta, Coloniae Agrippinae, sumptibus Petri Ketteler, 1683.

4 Nomenclator marianus, e titulis selectioribus quibus b. Virgo a ss. Patribus honestatur, Lugduni, apud haeredes Gabriel Boissat et Laurentii Anisson, 1639. Cito por la 
chrétienne", en palabras de Migne, Miguel Pexenfelder ${ }^{5}$. Poco más tarde, Joaquín de Santa María recoge bajo el nombre de "hieroglyphica Mariae" la significativa cantidad de 289 voces $^{6}$. Una verdadera enciclopedia es el denso prontuario del croata Lorenzo Crisógono, por su rica cadena de autoridades patrísticas, medievales y modernas organizadas según treinta símbolos, en los que predominan los botánicos. Se pueden usar como repertorios también aquellas colecciones de alocuciones que desarrollan en diferentes entregas un tema simbólico homogéneo, útiles en nuestro caso cuando se trata del tema floral. Así el teórico de teología mística Maximilano van der Sandt, que desarrolla discursos centrados siempre sobre una flor distinta ${ }^{8}$. Así el conocido antólogo de empresas Filippo Picinelli, con sus cincuenta discursos sobre otros tantos títulos marianos? Y lo mismo el afortunadísimo Jeremías Drexel con un tratadito significativo, además de por el material, porque empareja los dos procedimientos que guían esta proliferación metafórica: concentrar en un solo figurante la serie de los figurados, o exhibir la lista inmensa de los figurantes para el único figurado invariable ${ }^{10}$. Él, mientras desarrolla la argumentación en

edición definitiva, contenida en el séptimo volumen de las Opera omnia, Lugduni, H. Boisset-G. Remeus, 1665.

5 Hortus marianus symbolicis sacrae scripturiae plantis mysticis deiparae elogiis, moralibus LI allocutionibus consitus, Dillingae, typys et sumptibus Joannis Caspari Bencard per Joannem Federle, 1682.

6 Mystica anatomia sacratissimi nominis deiparae Virginis, Venetiis, apud Petri Antonii Brigoncium, 1690.

7 Mundus marianus siue Mariae speculum mundi sublunaris, Augustae Vindelicorum, impensis Philippi Jacobi Veith, 1712. La obra fue publicada póstuma; sobre el autor, A. Katalinic, De cultu mariano a saeculo VI ad saeculum XI in prima encyclopedia mariana a Laurentio Chrysogono Croato conscripta, en De cultu mariano saeculis VI-XI. Acta congressus mariologici mariani internationalis in Croatia anno 1971 celebrati, Roma, Academia Mariana Internationalis, 1972, vol. II, pp. 197-205.

8 Maria, flos mysticus, siue oraciones ad sodales in festivalibus [sic] deiparae habitae desumpta materia a floribus, Moguntiae, apud Godefridum Schönwetterum, 1629.

9 Simboli verginali agli onori di Maria, madre di Iddio, spiegati in cinquanta discorsi, Milano, Francesco Vigone, 1679.

10 Rosae selectissimarum virtutum quas Dei Mater orbi exhibet, 2 vols., Antvuerpiae, apud Joannis Cnobbarum, 1636-1637. Reimpreso en Opera omnia, Lugduni, sumptibus Joannis Antonii Huguetan et Marci Antonii Ravaud, 1658, en el vol. II, pp. 757-906, por el que cito. 
torno al único tema de la rosa, exhibiendo 29 variantes para indicar otras tantas virtudes marianas, inserta una lista de 408 títulos sacados únicamente de los Padres griegos; si no todos, la mayor parte son traslados. Repertorios son también las colecciones de emblemas y empresas marianas: para los primeros el Parcapium marianum de Juan David ${ }^{11}$; para las segundas el magnífico infolio de Celestino Sfondrati ${ }^{12}$, que acopia disciplinas tan diversas como la controversística y la teología simbólica, o bien la sección mariana en la desmesurada colección de Paolo Aresi ${ }^{13}$. Amplias compilaciones de metáforas y densas referencias a fuentes a veces rarísimas contienen de vez en cuando textos en apariencia más que alejados del área simbólica; por ejemplo Rutilio Benzoni ${ }^{14}$ cuando vuelve a recorrer puntillosamente la "via pulchritudinis" preguntándose "quaenam fuerit pulchritudo capitis virginis", y sucesivamente cabellos, ojos, nariz, boca, labios, dientes, cuello, collar, senos, vientre, estatura y paso, "et quipus similitudinibus explicentur”. Huelga decir que los instrumentos usados para esta verificación sobre una producción cuya consistencia está bien representada, a la altura de nuestra naturaleza muerta, en la más antigua, cuanto preciosa, bibliografía mariana de Hipólito Maracci ${ }^{15}$.

El más vasto tratado sobre esta materia, difundidísimo en manuscritos e impresos hasta el siglo XVII, cuando pasa bajo el nombre de san Alberto Magno, es el De laudibus beatae Mariae de Ricardo de San Lorenzo (siglo XIII), primer y riquísimo colector que combina la enciclopedia con una articulada glosa expositiva ${ }^{16}$. Ricardo avanza siguiendo ya los dos caminos indicados: las prerrogativas de María permiten la recolección de numero-

11 Publicado junto a otra colección de emblemas sobre la pasión que lleva por título Paradisus sponsi et sponsae, Antverpiae, ex officina Plantiniana, 1607.

12 Innocentia vindicata, in qua gravissimis argumentis ex s. Thoma petitos ostenditur angelicum doctorem pro inmaculato conceptu deipare sensisse et scripsisse, Pars prior theologica... Pars posterior symbolica, excudebat Jakob Müller, typis monasterii Sancti Galli, 1695.

13 Delle sacre imprese libro quinto, Tortona, Pietro Giovanni Calenzano ed Eliseo Viola, 1630.

14 Commentariorum ac disputationum in beatissimae virginis canticum Magnificat, Venetiis, apud Juntas, 1606, 3, 34.

15 Bibliotheca mariana alphabetico ordine digesta, Romae, typ. F. Caballi, 1648.

16 Ocupa el vol. XXXVII de la Opera omnia de san Alberto Magno en la edición Borgnet, Paris, apud Louis Vivès, 1890-1899. 
sas metáforas; y, viceversa, algunos símbolos de base, templo, huerto, permiten reunir bajo una clase homogénea una cantidad de figurantes. Los lejanos precedentes patrísticos de esta simbología se recogen, más allá de los repertorios postridentinos antedichos, de los índices de Migne y de Pitra; y, por la himnología, del repertorio de Salzer ${ }^{17}$. Es una literatura atractiva también porque cultiva disciplinas no teológicas: el iconólogo a la cabeza, pero también el filólogo medieval y moderno que se enfrenta con una poesía mariana que atraviesa todas las literaturas. También incluidos nuestros mayores, Dante y el Petrarca de la última canción, que ya con el primer epíteto que dirige a la virgen muestra su deseo de recorrer aquella "via pulchritudinis" que Ricardo de San Lorenzo había tan ampliamente delineado; una fuente, esta, que podría revelarse inmediata para Petrarca, sabiéndola ligada a la de Hugo de Santo Caro, cuyo comento bíblico se manifiesta en los Rerum vulgarium fragmenta ${ }^{18}$.

¿Qué relación enlaza una naturaleza muerta con los enunciados verbales de una literatura tan vasta? Ella inscribe indudablemente en la inmensa trama que enreda las expresiones de la fe proclamadas con la palabra a las manifestadas con la imagen, ambas remontadas a un solo depósito de creencia y de cultura. La imagen puede ser y no ser ilustración de un texto; el texto puede ser o no ser explicación de una imagen. Pero las dos partes se mantienen siempre en una relación recíproca. Ambas son elementos de un mismo sistema comunicativo, interdependientes, intercambiables en el papel primario de elucidar los contenidos que transmiten. El fiel puede apropiárselo porque detrás de ambas hay un material primario común, cuyo conocimiento hace funcionar la representación. Este material tiene su fundamento en la Biblia y en la hermenéutica que de la mismo dio la entera sociedad cristiana, desde la jerarquía hasta el pueblo menudo: es decir, por la iglesia. Signos verbales e icónicos se refieren en esta perspec-

17 Los nombres de María aparecen en el segundo volumen de los índices a la Patrologia latina, ocupando las columnas 495-522; el índice simbólico de Jean Baptista Pitra en Spicilegium solesmense, Parisiis, 1855, vol. III, pp. 614-622; Anselm Salzer, Die Sinnbilder und Beiworte Mariens in der deutschen Literatur und lateinischen Hymnenpoesie des Mittelalters, Darmstadt, Wissenschaftliche Buchgesellschaft, 1967 (anast.).

18 He ilustrado un pasaje significativo en "Passeri solitari sul Carmelo", Rivista di letterature moderne e comparate, 38, 1985, p. 125, nota 28. 
tiva al verbo e imagen divinos de los cuales cada reelaboración terrena no es sino reconocimiento. Es ahí donde se instaura la dialéctica entre la imagen y palabra, porque la palabra delinea la imagen y la imagen a su vez da forma a la palabra. Porque produce imágenes, el texto verbal puede ser ya fuente de inspiración, ya a su vez inspirador de la palabra, ya inconsciente punto de coincidencia con el contenido de la propia expresión.

Quien lee la imagen deberá adaptarse a esta alternativa, buscando en la literatura a veces la tesela textual inspiradora de la imagen o el texto consiguiente, a veces el código apto para descifrarla. La alternativa a la que se enfrenta el intérprete de esta naturaleza muerta es por consiguiente si leerla como un sintagma figural, matriz o traducción en imágenes de un determinado texto verbal, o bien si considerarla un aparato de figurantes simbólicos polisémicos, para los cuales la literatura, a modo de vocabulario, procura los sentidos deseados; precisamente los que se intuyen a decenas en los textos citados por cada uno de los elementos aquí presentes: lirio, rosa, jarrón, trono. La lectura del iconólogo va normalmente en esta dirección, creyendo una hazaña imposible repescar en el maremágnum de semejante literatura un texto sustraído y propuesto de modo tan enigmático. Y sin embargo un cuadro hecho para transmitir sentidos simbólicos contiene infaliblemente elementos aptos para definir entre muchos el sentido preciso de sus componentes metafóricos, de tal modo que solicita al intérprete que elija entre decenas de significados únicamente aquel que se adapte al caso concreto. Reconstruidos los conceptos partiendo de los elementos icónicos, traducibles después en palabras, se podrá finalmente, si fortuna asiste y memoria socorre, reunir el mensaje pintado con el texto verbal inspirador o derivado de él. Toda la teoría de la empresa se basa sobre este principio, porque si el cuerpo de la empresa es un mote polisémico virtualmente capaz de expresar muchos resultados semánticos, la empresa es dinámica, única, irrepetible ya en la representación del mismo cuerpo antes de la confección del mote. Es un procedimiento admirablemente descrito por el sumo teórico que fue Tesauro, bajo el lema de lo expresable: "lo que se escribe debe ser legible; y también lo que se pinta”. A propósito del cuerpo de la empresa, declaraba: "excelente aquella figura que por sí sola funda un argumento de semejanza", mostrando sin embargo la reserva de que "entre cuerpos naturales esta perfección es muy rara, porque su semblanza difícilmente puede significar algún pensamiento que no sea simple y general". Para obviarlo, continúa, 
el dibujo debe exhibir elementos que sepan individuar o la acción que los sujetos representan o la propiedad sobre la que se funda la semejanza. Al intérprete no le queda entonces sino dar en el blanco del signo de aquel elemento individualizador para reconstruir la intención del emisor ${ }^{19}$. Ahora en nuestra naturaleza muerta aparece un trazo individualizador de ese tipo, puesto de relieve por el artista con cuidado (y del que también se hace eco el marco): es la disposición artificiosa de los elementos. Un artificio que se impone tanto más a la mirada cuanto más contrasta con la representación realista de los objetos, retratados con magnífica destreza al natural. Un artificio que más reclama para sí la función de transmitir un mensaje cuanto más pertenece a un dato que es decisivo para cada lectura de un documento icónico: la repartición de los elementos sobre la superficie pintada.

\section{PRO Y CONTRA}

\section{Rosario y letanias}

Me declaro decididamente reacio a aceptar (porque no toma en cuenta este dato) una propuesta entre las más recurrentes en la valoración de los expertos: el rosario. No aparece de hecho ninguna conexión específica entre los elementos del cuadro y esa práctica, sino entre la onomástica de la devoción y la presencia de las rosas. Ciertamente el haber dado el nombre de rosario (literalmente "matojo de rosas") a una oración que nunca nombra a la rosa es un hallazgo metafórico singularísimo. El traslado se ha hecho posible por el hecho de que las avemarías repetidas han sido equiparadas a rosas ofrecidas a María por el devoto con un rito análogo a aquel del caballero que homenajeaba con rosas a la dama; son conceptos testimoniados ya desde el siglo XIII ${ }^{20}$. En la época del cuadro, el rosario

19 Emanuele Tesauro, Il cannocchiale aristotelico, Torino, per G. Sinisbaldo stamp., 1654, p. 728.

20 Sobre el origen del nombre y sobre el paso a corona, cfr. Gislind Ritz, "Der Rosenkranz”, en 500 Jahre Rosenkranz. 1475 Köln 1975, Köln, 1975, p. 57. Sobre el progreso de la investigación histórica en torno al debatido tema del origen del rosario, una clara síntesis en Joseph Klinkhammer, Die Entstehung des Rosenkranzes und Seine ursprüngliche Geistigkeit, ibidem, pp. 30-50. El estudio decisivo sobre la formación de la práctica pía es del mismo autor, Adolf von Essen und seine Werke. 
ya se había dejado de asociar al matojo de rosas, a favor de la corona, y esto desde haría ya mucho tiempo. La iconología de nuestro cuadro no coincide por este aspecto con la entonces habitual para designar la devoción: ni con la de la virgen del rosario, ni con la simbólica de la misma oración, ya antigua, pero entonces floridísima en concomitancia con la institución de una fiesta en honor de la "regina sacratissimi rosarii" 21 . Con mayor razón se excluye tal eventualidad cuando se constata que ni el reparto de los elementos sobre el cuadro ni su número corresponden con los de la oración, ni la forma actual de las 150 aves (que, habiéndose impuesto justo en el Seiscientos, será definitivamente sancionada en 1726), ni en las varias fórmulas que estaban todavía en $\mathbf{u s o}^{22}$.

Tampoco convence la referencia a las letanías como posibles inspiradoras del cuadro. El atributo de rosa se nos revela privilegiado en cuanto que oficializado en las lauretanas como único entre los muchos epítetos florales insertos en previas formas letánicas. Su sentido se ha clarificado de varios modos por los escritores espirituales, sin excluir la acepción más alta y propia que se pueda atribuir al término. Todos los títulos de las letanías, observa Antonio Vieira ${ }^{23}$, son místicos, pero se dice solo de la rosa, puesto que en los atributos se considera solo la semejanza, pero en la rosa se unen también las ventajas de la diferencia, porque en María hay que distinguir el cómo del cómo no y ello puede hacerse solo con el epíteto. Con todo esto, el cuadro, para referirse a las letanías, debería presentar o la rosa inserta en su lugar en la sucesión de las otras figuras letánicas (como sucede en la iconografía específica de la devoción) o, en el caso de que el autor quisiera privilegiar aquel atributo, la rosa rodeada

Der Rosenkranz in der geschichtlichen Situation seiner Entstehung und in seinem bleibenden Anliegen, Frankfurt a. M., Knecht, 1972 ("Frankfurter Theologische Studien", 13).

21 Describe los varios tipos iconográficos de la virgen del rosario y de los grafos que simbolizan la oración E. Wilkins, en Lexikon der christlichen Ikonographie, Rom-Freiburg-Basel-Wien, Herder, 1971, vol. III, s. v. "Rosenkranz".

22 Reúne la variedad de las coronas marianas con el número de invocaciones y su reparto Stephan Beissel, Geschichte der Verehrung Marias im 16. und 17-Jahrhundert, Freiburg B., Herder, 1910, pp. 44-59.

23 La rosa mistica, sermoni del rosario, Venezia, Domenico Lovisa, 1714. 
de las otras viñetas ${ }^{24}$. Las letanías no se pueden representar sino con un conjunto de figuras, porque está en la esencia de esta oración experimentar la virtualidad de un paradigma: los lirios puestos aquí junto a las rosas no bastan, también en la hipótesis de que el pintor se haya referido a un módulo letánico no oficial, que comprendiera la invocación bien testimoniada de "lilium convallium" 25.

\section{La "belle Charite"}

Más sutil es el argumento de la belleza, ya profana como sugiere Bologna, ya traspasada a María como pretende Zeri, porque invita a descender desde "pensamientos simples" a sentidos más restringidos. Rosas y lirios son figurantes recurrentes en la representación poética de la belleza física, pero con una tarea definida, la de designar el colorido de la piel; de modo más específico (especialmente cuando son acolados) indican el rojo y el blanco de las mejillas, de los labios y de los dientes. No hay duda de que en la tradición poética postpetrarquesca hasta su ocaso en el curso del Seiscientos, pero con significativas reviviscencias todavía en Porta, Manzoni y más adelante ${ }^{26}$, estos análogos figurantes, si bien con varia concreción, designan puntualmente partes del cuerpo femenino y no genéricos datos de su belleza. También los ejemplos aducidos oportunamente por Bologna, y son unos pocos entre miles, responden a este dato. Una vez aceptada la restricción, de la cual es garante la tradición poética, las preguntas que plantea nuestro documento son las siguientes: 1) ¿lirio y rosa pueden significar un rostro, humano o divino, por el solo hecho de encontrarse en una composición de naturaleza muerta?; 2) ¡la disposición de los elementos en el cuadro puede aludir a la de las partes de un rostro humano?

La primera apunta a las posibilidades mismas de la pintura para representar una metáfora. Cuando la pintura representa el figurante y

24 Sobre la iconografía de las letanías, Lore Lüdicke-Kaute, en Lexikon der christlichen Ikonographie, vol. III, s.v. "Lauretanische Litanei"; Stephan Beissel, Geschichte der Verehrung Marias im 16. und 17. Jahrhundert, pp. 487-89.

25 Véanse los casos en Gilles Gèrard Meersseman, Der Hymnos Akathistos im Abendland, Freiburg S., Universitätsverlag, , vol. II: Gruss-Psalter, Gruss-Orationem, Gaude-Andachten und Litaneien, 1960, pp. 228, 244, 252.

26 Véase Giovanni Pozzi - Dante Isella, "In onore di Carlo Porta", Archivio storico ticinese, 69 (1977), pp. 45-47. 
el figurado de una metáfora, la mente puede asociar los dos términos al mismo nivel con el que une los dos términos lingüísticos. Esto es más fácil cuando un discurso verbal acreditado sirve de soporte a la imagen y es al mismo tiempo tan familiar que se puede fácilmente captar su presencia en el cuadro. Por esto opté por interpretar como prestamos de la mujer poética algunos supuestos retratos femeninos de desconocidos, porque la mujer aparece allí rodeada por los mismos objetos que en poesía son los figurantes del cuerpo femenino ${ }^{27}$; quienquiera que tenga práctica en la sonetería amorosa, une los espejos, las joyas, las perlas y las rosas a los figurantes habituales en los poetas, descartando la idea realista de la mujer en su tocador.

Cuando en cambio no existe lo figurado, el sentido simbólico se clarifica solo si los objetos representados están fuertemente codificados: una espiga y un racimo significan indudablemente eucaristía; lo que puede valer también para un solo objeto: un cordero es Cristo, un lirio es pureza. En los casos en los que la codificación sea menos rigurosa, y más aún en coincidencia con el modo naturalista de retratar las cosas que es propio de la naturaleza muerta, el significado metafórico se puede aprehender solo o porque los objetos presentes, si no codificados uno por uno, entran sin embargo a formar parte de un conjunto que lo es como tal, o porque objetos no codificados son colocados junto a otros que lo están, de modo que la presencia de estos transmita también a aquellos el sentido deseado.

Son lances que dependen de lo que la pintura puede o no puede representar; toda la pintura en general, pero especialmente cuando elige el paradigma de la naturaleza muerta. La pintura representa al vivo la morfología de una flor, sus colores, sus cualidades táctiles, pero no puede hacer entender que sean motivaciones de una metáfora (a menos que la flor no resulte fuertemente codificada e insólita, como podría ser la pasiflora). La pintura podría jugar con los simbolismos de las variedades botánicas de la rosa, como hacen en el área verbal los citados Van der Sandt y Drexel, pero de hecho no conozco un Ligozzi o un Redouté mariano. Las otras propiedades sobre las que los escritores hilvanan infinitas metáfo-

27 He hablado de ello en "Il ritratto della donna nella poesia d'inizio Cinquecento e la pintura di Giorgione”, en Giorgione e l'umanesimo veneziano, pp. 331-36. 
ras continuadas o seguidas, las virtudes medicinales, los perfumes, se le escapan irreparablemente.

La primera eventualidad arriba descrita, la del conjunto significante en cuanto tal, está bien representada por las "vanitates", donde calavera, espejo, vela, reloj afirman, cuando son reunidos, el sentido del cuadro; una vela solitaria o un reloj, de por sí no predican vanidad ${ }^{28}$. Para la segunda, evoco el caso de la mosca: posada sobre un cráneo significa corrupción y muerte; posada sobre una cortina o un sombrero, es solo una mosca. Es el cráneo el que hace de ella un significante ${ }^{29}$.

La tradición literaria ha codificado lirio y rosa como figurantes del rostro femenino junto a cantidad de otros elementos: ámbar, oro, ébano, perlas, rubíes, nieve, leche, vino, sangre, etc. Me pongo ojo avizor, como he dicho, frente a una naturaleza muerta que exponga todos o una parte notable de estos objetos, porque recibo señales unívocas en serie que remiten al completo paradigma de ese topos literario. Pero en una naturaleza muerta en la que están presentes solo lirios y rosas (aunque con profusión) no estoy seguro de ver evocado el topos poético de la belleza: 1) porque se presentan solo dos elementos de la serie; 2) porque lirio y rosa tienen en el repertorio metafórico muchos otros significados que van más allá del campo semántico de la belleza física.

Con la segunda pregunta nos cuestionamos si la disposición de los elementos del cuadro puede referirse a la de las partes anatómicas del rostro humano que lirio y rosa suelen representar: las mejillas y la boca. Voy a ser breve. Aquella edad cargada de extravagancias no ha dejado de inventar varias también en el ámbito de este tema: dígalo la Primavera de Arcimboldi con el rostro materializado de rosas, habla el atónito "portrait par métaphore" de una "bella Caridad" ideado por Carlos Sorel en el Berger extravagant ${ }^{30}$. Pero sería otra forma

28 Sobre la infinita bibliografía en torno al tema recuerdo los reiterados estudios de I. Bergström, sintetizados en la introducción a Natura in posa, p. 26; Jósef Grabsky, "Perfectionis vanitas", en Scritti di storia dell'arte in onore di Federico Zeri, Milano, Electa, 1974, vol. II, pp. 709-717; y el catálogo Vanitas. Il simbolismo del tempo de la galería Lorenzelli, 1981.

29 André Chastel, Musca depicta, Milano, F. M. Ricci, 1984, pp. 11-36.

30 John Humphreys Whitfield, "La belle Charite: The Italian Pastoral and the French Seventeenth Century", Italian Studies, 18 (1963), pp. 33-53; Leonard Forster, The 
bien distinta de sorprender el dibujo de un grafo del rostro humano, reducido a mejillas y boca, usando elementos retratados y colocados en una pose al natural, y no por ello menos investidos de funciones metafóricas. Bizarrías de otro tipo y propias de nuestra época, pero no menores que aquellas, son las sugerencias hermenéuticas que se refieren "al implícito, casi atávico analismo que descubren las corolas", y a las "auras heterodoxas y esotéricas" que transpiran desde allí; no lo discuto porque no son reductibles con el tema de la bendita entre las mujeres ni con el ánimo de un devoto postridentino suyo. Sapientes ipsi videant.

\section{María toda bella}

Se puede imaginar, si no, que las dos flores, bellas entre las bellas, pueden aludir a una hermosura genérica, más espiritual que anatómica, especialmente hacia la que es proclamada "tota pulchra", como insinúa explícitamente Zeri. Para salir "de los pensamientos generales", conviene también aquí referirse a la tradición literaria, no a la profana de Guinizelli en adelante, sino a la específicamente mariana. Allí, por cuanto he constatado, lirio y rosa, cuando no significan cualidades interiores del ánimo, son empleadas para designar, ni más ni menos que en el ámbito profano, el color de la tez de la virgen. Es un problema tratado con largueza en el contorno de una especulación que durante siglos se ha interrogado sobre la belleza de su físico, reseñando los miembros ni más ni menos de lo que se hacía sobre la otra vertiente. Iniciada con los bizantinos Cedreno y Nicéforo Calisto Xantópulo ${ }^{31}$, la indagación ha llegado hasta el detalle más menudo con Ricardo de San Lorenzo, que le dedicó completo el libro V del De laudibus, y con el pseudo-Alberto Magno, Mariale siue quaestiones super Evangelium Missus est, que inauguró otra argumentación, basada sobre la armonía de los temperamentos, ineluctablemente máxima en ella ${ }^{32}$.

Icy Fire. Five Studies in European Petrarchism, Cambridge, University Press, 1969, p. 57.

31 Cedreno en el Historiarum compendium, PG 121, col. 363; Xantópulo en la Historia eclesiástica, $P G$ 145, col. 815.

32 Ocupa las cuestiones 15-20 en la edición Borgnet de Alberto Magno, vol. XXXVII, pp. 36-47 (vid. supra); las tres últimas desarrollan el tema del color de la piel, de los 
A partir de entonces se optará por una u otra vía; o se yuxtapondrán ambas a lo largo de una "via pulchritudinis" ininterrumpida hasta bien entrada la época de nuestro cuadro. Es un argumento dejado en sombras por la moderna mariología histórica debido quizá a una inconsciente censura, pero no descuidado todavía por la religiosidad postridentina, deteniéndose en rediscutir sus argumentos la cautela de un Pietro Cani$\operatorname{sio}^{33}$ y la acribia severa de un Teófilo Raynaud ${ }^{34}$. Lirios y rosas aparecen mezclados con una multitud de otros figurantes; para el citado Ricardo de San Lorenzo las mejillas de María son "lilium cum rosa", los labios tienen "exterius colorem lilii, interius rosae", las manos "quaedam lilia candidissima sunt"; Dionisio el Cartujano en la "commendatio uberum" de María $^{35}$ recuerda labios de rosas, frente de nieve, guedejas de oro. $\mathrm{Y}$ así otros, pero no con excesiva frecuencia. La veta mariana se atiene casi exclusivamente a las metáforas que usa el Cántico cuando describe al amado $(5,10-16)$ y a la amada (7, I-9), coronadas por otras no necesariamente referidas por la Biblia a partes anatómicas, aunque siempre bíblicas: si el lirio es del Cántico y designa la belleza física, la rosa no lo es y no designa nunca en la Biblia la belleza. Ricardo de San Lorenzo enumera para rojo y blanco la granada $(C t, 6,6$ "cortex mali punici"), el vino y la leche ("meliora ubera tua vino", $C t$, I, I y 4, 10); para el blanco, la nieve (Lam, 4, 7 "candidiores nive"), túnica, leche, marfil; para el rojo, la zarza ardiente, la estrella rutilante $(N m, 24,17)$, el coco, la llama, el hierro incandescente $(D t, 4,24)$, la hogaza de Salomón "cuius ascensus purpureus" (Ct, 3, 9-10). El conjunto de los figurantes, como se ve, es en gran parte diverso del de la veta secular. Esta, con poner los ojos sobre la Biblia y especialmente sobre el Cantar (baste recordar la conclusión de la Rota Veneris de Boncompagno da Signa), no razona sin embargo en la misma línea seguida por el tema sagrado.

Conozco solo un caso en donde los argumentos marianos sean transferidos sin más al tema profano de la mujer bella: el elegante libelo de Ernesto

cabellos y de los ojos.

33 De Maria, Virgine incomparabili et Dei genitrice sacrosanta, Ingolstadii, exc. D. Sartorius, 1577, 1. I, c. 13.

34 Diptycha mariana..., en Opera omnia, vol. VII, 2 (vid. supra).

35 De dignitate et laudibus beatae virginis, 1. I, art. 23, en Opera omnia, Tournai, Chartreuse de Notre-Dame-des-Prés, 1908, vol. XXXVI. 
Vaenius $^{36}$, ornado de graciosísimos grabados que reproducen también los esquemas fisiognómicos de Della Porta; allí los materiales profanos y sacros se entrecruzan con los trazos de la medicina y la fisiognómica, a imagen de cuanto hacen en otra vertiente un Pelbarto de Themeswar ${ }^{37}$, un Rutilio Benzoni $^{38}$, tardíos y extenuados especuladores sobre la realidad corpórea de la virgen. El argumento de la diversidad de los figurantes, cardinal como índice de dos tradiciones separadas ya en sus fuentes, se muestra sin embargo secundario en el cotejo con el que deriva del distinto funcionamiento del topos en cuanto entidad estructurada como sistema. Contrariamente a la tradición de la poesía secular, en la literatura mariana las metáforas siguen representando un repertorio enumerativo, no forman el sistema opositivo de figurantes que en aquella involucra ya al aparato anatómico ligado a los figurantes, ya al aparato cromático ligado a las motivaciones ${ }^{39}$. Al contrario, incluso quien construye un sistema cromático idéntico al del canon de las bellezas femeninas, con blanco, rojo, amarillo y negro, como san Antonino de Florencia ${ }^{40}$, no se atreve a referirlo a un sistema anatómico, puesto que hace corresponder, esta vez hablando de Cristo, el blanco al cuerpo, el rojo al alma, el amarillo a la divinidad, el negro a la persona humana. Son representaciones tan abstractas que no pueden ser incorporadas en los elementos naturales de una naturaleza muerta, por más alegorizante que se pretenda que esta sea. En el cuadro de una tradición similar, lirio y rosa son todavía menos adecuados para evocar las bellezas de María que las de la mujer terrena.

36 Tractatus physiologicus de pulchritudine iuxta ea quae de sponsa in Canticis Canticorum mystice pronunciantur, Bruxelles, typis Francisci Foppens, 1662.

37 Stellarium coronae gloriosissimae virginis, Venetiis, apud Ioannem Antonium Bertanum, $1586,1.5$, p. 3 , a. 2.

38 Commentariorum..., 1. 3, c. 34.

39 He desarrollado este argumento para la poesía profana en "Temi, topoi, stereotipi", en Letteratura italiana, a cura di Alberto Asor Rosa, Torino, Einaudi, vol. III, I: Le forme del testo. Teoria e poesia, 1984, pp. 398-411, 418-20. Sobre la motivación del color como generador preeminente de las metáforas del lirio y la rosa en el ámbito completo de la literatura alegórica sacra, de los Padres en adelante, ya sea cuando designan a Cristo como a los santos u otra cosa, cf. Jennifer O’Reilly, Candidus et rubicundus. An Image of Martyrdom in the "Lives" of Thomas Becket", Analecta Bollandiana, 99 (1981), pp. 303-14.

40 Summa theologica, I, 3, 3, 3. 
En el ámbito de la "via pulchritudinis" se presenta otra solución, dudosa pero no desdeñable a priori. Testimoniada ya desde el siglo XII, se difundió mucho más entre el siglo XV y el XVI una "salutatio membrorum" de la bendita virgen ${ }^{41}$. Santa Brígida de Suecia, entre las plegarias que le fueron confiadas por divina revelación (cuya autenticidad es dudosa), tiene una larguísima donde aparecen también las rosas de los labios y el lirio del cuello ${ }^{42}$. La práctica pía sigue bien viva más allá de la época del cuadro: Cristoforo Verucchino enumera treinta y seis miembros de María, después de una introducción sintética que evoca arterias, músculos, nervios y colores ${ }^{43}$; Ignacio Carnago, capuchino como el anterior y por ello consignatario de una piedad destinada a larga difusión popular, reduce la práctica a una retahíla de avemarías; una vez absorbido el contenido específico de las singulares invocaciones en la universal oración mariana, quedaban las rúbricas para indicar el destino ${ }^{44}$. Se debía recitar la oración ante una imagen particularmente bella, para recorrer en sucesión sus miembros del mismo modo que se recorren en la lectura las páginas de un libro, dice Alano de la Roche ${ }^{45}$. Quizá por esta costumbre Juan Mombaer, férvido difusor de la "devotio" moderna, impone al lugar de una efigie al natural un icono espiritual, para evitar los peligros de la imaginación ${ }^{46}$; una alerta siempre viva en estos maestros del espíritu, y tanto más en coincidencia con un argumento tan delicado. Espirituales

41 T. Esser, "Über die allmähliche Einführung der jetzt beim Rosenkranz üblichen Betrachtungspunkte", Der Katholic Zeitschrift für katholische Wissenschaft und kirchliches Leben, 30, 1904, p. 290; 32, 1905, p. 348; Stephan Beissel, Geschichte der Verehrung Marias in Deutschland während des Mittelalters, Freiburg B., Herder, 1909, p. 290; Geschichte der Verehrung Marias im 16. und 17. Jahrhundert, p. 48.

42 Revelationes sancte Brigitte, olim a cardinali Turrecremata recognitae, a cura di Consalvo Duranto, Romae, apud Stephanum Paulinum, 1606, orat. 4.

43 C. Verruchino, Compendio di cento meditazioni sacre sopra tutta la vita e la passione del signore come della madonna, Venezia, Niccolò Miserino, 1617, pp. 604-13 (meditazione 91).

44 Manuale dei servi di Maria, Cremona, Giovanni Pietro Zanni, 1658, 1. 2, c. 2, par. 2.

45 T. Esser, Über die allmähliche Einführung..., p. 290.

46 En el Rosetum exercitiorum spiritualium et sacrorum meditationum, Parisiis, Josse Bade pour Jean Petit et Johannes Schabeler, 1510, sect. 12, un texto reimpreso hasta el Seiscientos. 
son las imágenes que en lugar de la realidad física ofrecen una visión simbólica de la anatomía venerada. Lirios y rosas aparecen en las "salutaciones” verbales junto al repertorio metafórico que acompaña generalmente a la especulación sobre las bellezas marianas (lo he evocado arriba para la "salutatio" de Santa Brígida). Lirios y rosas en un cuadro espiritual parecen representar entonces una sustitución delicada que intenta evocar por litote solo la parte más noble del físico, el rostro (de acuerdo con el canon breve que era obligado en la poesía profana más elevada), así como seleccionar por antonomasia los figurantes más selectos. La explicación descansa sobre razones plausibles; no aclara sin embargo por qué el pintor ha dispuesto en un orden tan singular sus lirios y sus rosas.

\section{María lirio - Cristo rosa}

Mucho más atractivas, especialmente cuando (como en el caso de Zeri) se toma en cuenta aquella disposición, son las interpretaciones que representan en las flores pintadas la persona misma de María, o la de Cristo, o las dos contemporáneamente. La metáfora puede funcionar aquí de dos modos: I. los dos figurantes designan al mismo individuo; 2. cada uno lo designa separadamente.

Lirios y rosas agrupados indican solo la persona de la virgen en muchísimas recurrencias de sus alabanzas. La piedad floral ha atribuido a María poco menos que el repertorio botánico entero, ora detallando para cada flor su atributo, ora reuniendo la flora completa para elogiar su nombre; son dos desarrollos de un único y célebre tema, el del hortus conclusus, que comprende infaliblemente también lirios y rosas, pero que nada tiene que ver con nuestro cuadro. Otro e independiente de este es el motivo que asocia las dos flores en la pura y simple representación de María. Tiene por cierto un punto de apoyo en rerum natura, siendo las dos flores más espléndidas de la creación. Pero el fundamento verdadero está en la Biblia, o sea, en las traducciones griegas y latinas que han determinado con esa onomástica los inciertos términos botánicos del original; ha colaborado poderosamente a fijarlo la hermenéutica alegórica, que asignó a María, reuniéndolas en un sintagma, las menciones de lirio en Ct. 2, I-2 y 7, 2 y de rosa en Sir, 24, 18; 39, 17 y 50, 8. Por ello Pexenfelder ${ }^{47}$ las llama “ornatissimi Mariae clientes".

47 Hortus marianus..., p. 32. 
La reunión de los dos figurantes en un solo cuerpo sintáctico reaparece con frecuencia en la himnología: "Ave lilium, ave rosa speciosa" la saluda el himnógrafo de la Laus beatae Mariae adscrita equivocadamente a san Bonaventura; e incluso, espigando entre himnos y secuencias: "Gratia te reddidit cunctis gratiosam, Te vestivit lilio, sparsit in te rosam"; o bien "Tu rosa, tu lilium, Cuius Dei filium Carnis ad connubium Traxit odor"; y así sucesivamente ${ }^{48}$. En paralelo para Cristo. El atributo "flos Mariae" se remonta a san Ambrosio; Cristo es asociado con María al lirio por san Pedro Damiani, In nativitate sanctae Mariae: "Lilium vocatur Christus, lilium dicitur et Mater Christi"; el tema de Cristo-rosa se desarrolla por extenso en la Vitis mystica, 15-17 de san Bonaventura ${ }^{49}$. Por cuanto bien ratificada por los testimonios literarios, la aplicación del motivo a nuestra naturaleza muerta no convence sin embargo, porque si explica la asociación de los dos figurantes, no explica su disposición sobre la superficie del lienzo. Se detiene en los pensamientos simples y generales de los que habla Tesauro, sin dar con su principio individualizador.

La otra posibilidad es que lirio designe a una persona y rosa a la otra; ambas metáforas son ambivalentes en la tradición alegórica, aun cuando sea más frecuente, debido al género gramatical, la atribución del lirio a Cristo y de la rosa a María. Pero a través de las guirnaldas mixtas de una flor y otra, será necesario, interpretando el cuadro, atribuir a un personaje la completa combinación de rosa y lirio, y al otro solo la rosa, representada en el ramo. Argumentos de este tipo subyacen en la exégesis de Zeri, que ve traducida en naturaleza muerta la iconografía antigua de la virgen en

48 El primer trozo citado responde al íncipit de la composición que se lee entre las obras espurias de san Buenaventura en la edición Quaracchi, vol. X, 21. El segundo, atribuido a san Pedro Damiani, aunque espurio, en L'opera poetica di S. Pier Damiani, a cura di Margareta Lokranz, Stockholm, Almquist \& Wicksell, 1964, pp. 155, 208. El tercero en Franz Joseph Mone, Lateinische Hymnen des Mittelalters, Freiburg B., Herder, 1854, vol. II, p. 404, n. 589 inc. "Mariae praeconio"; Clemens Blume - Guido María Dreves, Analecta Hymnica Medii Aevi, Leipzig, Reisland, 1866-1922, vol. LIV, p. 391, n. 249.

49 El texto de san Pedro Damiani, "Sermo XLVI. In nativitate Sanctae Mariae, 10", en Sermones, a cura di Giovanni Luccesi, Brepols, Turnhoult, 1983, p. 282 ("Corpus Christianorum. Continuatio mediaevalis”, 57); el texto de la Vitis mystica, 15-17, en la Opera Omnia de san Bonaventura, vol. VIII, pp. 180-183; el pasaje pertenece a las partes auténticas del opúsculo. 
trono con el niño sobre la rodilla. Él lee así el cuadro como un verdadero sintagma icónico, y no olvida el elemento individualizador de la disposición de las guirnaldas que abrazan el ramo de rosas. No falta en apoyo de su hipótesis alguna referencia literaria, como el himno de tercia de las Horae beatae Mariae Virginis: "Mater aeterni lilii, Per Quam Christus flos montium Flos factus est convallium. O dilecta cum dilecto, O electa cum electo, $\mathrm{O}$ rosa cum lilio" ${ }^{50}$. Obviamente no hay que acogerse a un texto paralelo para explicar la factura del cuadro, ni debe necesariamente apoyar su lectura. El indicado es demasiado remoto como para creerlo conocido por nuestro pintor. La reserva concierne más bien al traspaso iconológico en sí, en cuanto que se aferra solo oblicuamente al tema individualizador de disposición de las flores.

\section{Circumdabat eam}

\section{Una antifona pintada}

Si partiendo exclusivamente del cuadro, traduzco en palabras los datos de aquella disposición en los mismos términos con los que lo observo con el ojo, me asalta espontánea la frase: "lirios y rosas rodean un jarrón de rosas". El enunciado, banal en su aspecto, insignificante por su sonido, adquiere enorme resonancia para quien, provisto de alguna familiaridad con textos litúrgicos, se percata de su perfecta equivalencia con la parte final del responsorio Vidi speciosam, presente ya desde el antiquísimo rezo de maitines de la fiesta de la asunción: "Et sicut dies verni circumdabant eam flores rosarum et lilia convallium" 51 .

A condición, que quede claro, de que la “eam-Maria” de la antífona esté representada por las flores centrales. Y lo está, ya que se concentran ahí tres clarísimas alusiones marianas: en el jarrón, en su color negro y en las rosas. Sobre las rosas, es inútil volver; basta con apuntar que el atributo

50 Blume-Dreves, vol. XXX, p. 133, n. 58.

51 "Y como un día de primavera la rodeaban flores de rosas y lirios de los valles". Se recupera en el Corpus antiphonalium officii, a cura di René Jean Hesbert e René Prevost, Roma, Herder, 1963, vol. II, n. 106c y d, in assumptione y n. 109b, in nativitate. 
de reina de las flores se evoca en concomitancia con el misterio de la asunción, donde se proclama a María reina de los santos.

El ramo se compone de rosas exclusivamente rojas, porque deben designar la púrpura real con la que se viste la virgen asunta, púrpura "a Deo contexta" como dice Lorenzo Crisogono ${ }^{52}$ cuando, aduciendo, según suele, gran cantidad de autoridades, se interroga "cur virgo velut rosa inter flores regia purpura digna habeatur". El atributo del jarrón se ha hecho popular a través de las letanías lauretanas, pero su uso es antiguo y vasto, proviniendo de la Biblia. El color negro remite también a un versículo de $C t, 2$, 4, utilizado de manera específica también como antífona en el mismo oficio de la asunción ("Nigra sum, sed formosa”). Asimismo, quizá la transparencia del vidrio, que deja entrever los tallos de las rosas, aluda a la metáfora mariana del cristal; véase Ricardo de San Lorenzo: "Vere enim quasi vitreum fuit virginis corpus, quia quamvis de cinere humanae naturae, tamen cinis ille colatus per ignem Spiritus sancti transiit quasi in splendorem et puritatem vitri" 53 .

¿Pero qué significarán las dos guirnaldas de lirios y rosas? El sentido del responsorio se ha explicado desde antiguo en un texto famoso por tratarse de un contrafactum perpetrado bajo el nombre de san Jerónimo. Creído auténtico hasta Erasmo y Baronio, fue incluido por ello en el cuerpo de sus epístolas. Es probablemente de Pascasio Radberto y se cita por su íncipit, Cogitis $m e^{54}$. El tema de la epístola-tratado es precisamente el de la asunción de María: el pasaje que nos interesa es el siguiente:

52 Mundus marianus..., disc. 18, par. 10.

53 "En realidad el cuerpo de la Virgen fue casi vítreo, porque, aun compuesto de las cenizas de la naturaleza humana, aquellas ceniza, forjada por el fuego del Espíritu santo, adquirió el esplendor y la pureza del vidrio" (De laudibus..., l. 12, c. 5, par. 4).

54 Editado críticamente y comentado por Albert Ripberger, Der pseudo-Hieronymus Brief IX "Cogitis me". Ein erster marianischer Traktat des Mittelalters von Paschasius Radbert, Freiburg S., Universitätsverlag, 1962 ("Spicilegium friburgense. Texte zur Geschichte der kirchlichten Lebens”, 9). Los pasajes aquí reproducidos en los cap. 89-92, 87, 91. La dependencia de Pascasio respecto a la antífona litúrgica la afirma Georges Frenaud, "Le culte liturgique de Notre-Dame", Revue grégorienne, 31, 1952, p. 106; sobre las relaciones con la liturgia, William Cole, Theology in Paschasius Radbertus Liturgy - Oriented Marian Works, en De Cultu mariano saeculis VI-XI. Acta congressus mariologici mariani internationalis in Croatia anno 1971 
Ad cuius [Mariae] profecto fragrantiam odoris, omnis illa caelestis Hierusalem laeta decurrit, quam circumdabant flores rosarum et lilia convallium, eo quod omnes animae martyrio rubricatae eam aeternae dilectionis complectuntur amplexibus, et virginitatis splendore candidatae acsi lilia in valle humilitatis enutritae circumdant eam venerationis gratia obsecuentes. Recte igitur, quoniam beata Dei genitrix et martyr et virgo fuit ... Nunc autem circumdant eam flores rosarum, indesinenter eius admirantes pulchritudinem inter filias Hierusalem, in qua posuit rex thronum suum, quia concupivit eius speciem ac decorem; fuit enim plena caritate et dilectione. Idcirco sequitur post eam purpuratorum exercitus et candidatorum grex. Quam si diligentius aspicias, nihil virtutis est, nihil speciositatis, nihil candoris gloriae, quod ex ea non resplendeat. Et ideo bene circumdant eam flores rosarum et lilia convallium, ut virtutes virtutibus fulciantur et formositas decore castitatis augeatur. Nam omnis splendor et gloria, quanto illustratur fulgore suo sublimius, tanto apparet praestantior claritate quorumlibet subiectorum et eximior praedicatur. Sic et beata Dei genitrix, cuius candor virginitatis acsi plantatio rosae in Iericho specialius refulsit, circumdata officio caritatis splendidius enituit ${ }^{55}$.

celebrati, Roma, 1972, vol. II, 395-431; allí también R. Rossini, Il culto della B. Vergine nella lettera "De assumptione Sanctae Mariae Virginis" ("Cogitis me") dello Pseudo-Girolamo, pp. 433-59.

55 "A cuyo fragante perfume [de María] feliz acude toda la Jerusalén celeste. La rodeaban rosas floridas y lirios de los valles, en cuanto todas las almas coloradas del martirio la abrazan en amplexos de eterna dilección, y aquellas hechas luminosas por el esplendor de la virginidad, casi lirios nutridos en el valle de la humildad, la rodean obsequiándola con veneración. Justamente, porque la bendita engendradora de Dios fue mártir y virgen... Y ahora la rodean rosas floridas, admirando sin descanso su belleza en medio de las hijas de Jerusalén, por la cual el rey puso su trono en ella, habiendo deseado su hermosura y su decoro. Fue de hecho llena de caridad y de dilección; y por ello la sigue el coro de los purpúreos y el rebaño de los cándidos. Si tú la observas con diligencia, no hay virtud, ni belleza, ni esplendor, ni gloria que no resplandezca en ella. Y por ello es justo que la rodeen rosas floridas y lirios de los valles, para que las virtudes incluso aumenten si se confrontan con la virtud y la belleza aumentada por el decoro de la castidad. De hecho todo esplendor de gloria, cuanto más se hace luminoso por su fúlgida viveza, tanto aparece con más prestancia en la diferencia con lo que es menor; y así es proclamado mejor. Del mismo modo la bendita engendradora de Dios, cuyo esplendor virgíneo, casi rosa plantada en Jericó, refulgió de modo especial, rodeada por el fervor de la caridad brilló de modo más espléndido". 
Lirios y rosas son por tanto las vírgenes y los mártires que rodean a María alabándola, circundada de virginidad y martirio, de castidad y caridad. La paráfrasis de Radberto recoge así en un solo sintagma una buena parte de los atributos opositivos que forman, como he dicho al inicio, el paradigma de los significados marianos asignados al lirio y la rosa. Dos son las celebraciones paradisíacas en su honor que describe Pascasio: una, que se realizó al entrar su alma en el cielo; la otra, eterna liturgia de los santos en torno a su reina: "Credimus... quod non hunc tantum diem solemnem ducunt pro eius honore annuum, rerum continuum etiam et aeternum" 56 .

Y poco después, las palabras incluidas en el pasaje antedicho: “indesinenter eius admirantes pulchritudinem inter filias Hierusalem, in qua posuit rex thronum suum, quia concupivit eius speciem".

Aquí cita otro responsorio del oficio de la asunción ("Veni electa mea et ponam in te thronum meum") que puede remitir a la forma de la base sobre la que se apoya el jarrón; su semejanza con los tronos de ciertas pinturas marianas no se les escapa a Zeri y Gregori. La asociación de rosas y lirios a mártires y vírgenes no es de Pascasio; es de Jerónimo, a quien se le atribuye su composición, y que se refiere a ella precisamente en una epístola dirigida a Eustoquio que tiene por tema las alabanzas de Paula (Ep., 108, 31), o las dos presuntas destinatarias del apócrifo Cogitis me. La paráfrasis de Pascasio atañe a significados que eran ya adquiridos; desde entonces, y por siempre, hasta la época del cuadro y más allá, el orante que en el oficio de la virgen recita el responsorio sabe que la frase describe la gloria de María reina de los santos en la forma de un enunciado metafórico lleno de vaguedad en su exterioridad referencial ${ }^{57}$. Cuatro siglos

56 "Creemos... que celebran no solo esta recurrencia anual en su honor, sino una fiesta continua y eterna".

57 No puede aducirse a favor de la hipótesis del rosario, ya antes rechazada, el hecho de que el responsorio Sicut dies verni se encuentre en el oficio del primer nocturno para la fiesta del rosario, porque las fechas no coinciden con las ante quem del cuadro. Una fiesta del rosario aparece en Roma en 1571; extendida a la orden dominica en 1573, recibió un oficio justo en 1603, en el cual sin embargo el responsorio no figura, ni figurará en las sucesivas ediciones del breviario dominico hasta 1759; cfr. Monumenta Ordinis Praedicatorum Historica, vol. X, 293 y vol. XIV, 254. Consulto un opusculito de 1715 con el suplemento para un "officium novum" del rosario que 
después Ricardo de San Lorenzo sintetizaba el argumento de Pascasio remitiendo a su vez al responsorio donde este lo había encontrado:

Ingressa est Ierusalem multo cum comitatu... Comitatus ille de quo hic fit mentio designat solemnem illam hodiernam processionem angelorum et sanctorum quam Mariae virgini assumptae in coelum ad aethereum thalamum, in quo rex regum stellato sedet solio credimus obviam processisse... Interfuisse creduntur et martyres huic processioni, cum quibus eidem non defuit Gloria martyrii. Quod quia in ea parte quae impassibilis est, sicut dicit Hieronymus, hoc est in anima, passa est plusquam martyr, non immerito censetur. Et sicut virgo virginum, sic et martyr martyrum appelatur. Et idcirco canit ecclesia in hac solemnitate: "Sicut dies verni circumdabant eam flores rosarum et lilia convallium”. Per flores rosarum martyres suo sanguine purpurati, per lilia convallium casti et humiles designantur ${ }^{58}$.

Cuatro siglos más tarde Lorenzo Crisógono ${ }^{59}$ aún volvía sobre el mismo pasaje para describir cómo María "velut rosa inter omnes beatos praefulsit purpurata charitate". Lo que comporta no solo una transmisión lineal a lo largo de los siglos, sino la presencia contemporánea de todos los testimonios, de los más antiguos a los más recientes, de Pascasio a Crisogóno y otros, por medio de la continua reimpresión. Todavía más que esta literatura devota, que sin duda circulaba entre predicación y oración mental entre los fieles, su ininterrum-

se añade al breviario esta vez romano: no figura; tampoco figura en una edición de 1732.

58 Entró en Jerusalén con gran séquito... El séquito aquí recordado designa la solemne procesión que hoy cumplen los ángeles y los santos que salen al encuentro de María virgen asunta en cielo para ocupar el etéreo tálamo en el cual el rey de reyes se sienta como sobre un trono de estrellas... Se cree que tomaron parte en esta procesión también los mártires, porque a ella no le faltó como a ellos la gloria del martirio. No le faltó porque justamente se cree (lo dice san Jerónimo) que en la parte en la que no se padece, o sea, el alma, ella penó más que un mártir. Y por ello es llamada mártir de los mártires del mismo modo que allá se le dice virgen de las vírgenes. Sobre este motivo canta la iglesia en esta solemnidad: "Como un día de primavera la rodeaban flores de rosa y lirios de los valles". Las flores de rosa designan a los mártires rojos por su sangre, los lirios de los valles a los castos y a los humildes" (De laudibus..., l. 6, c. 13, par. 4).

59 Mundus marianus, disc. 18, par. 20. 
pida presencia en la liturgia hacía familiar la antífona y su significado. Una presencia ya no restringida a la igualmente sublime solemnidad de la asunción por cuanto el responsorio (al menos desde el siglo XVI) había entrado en el primer nocturno del oficio privado de la virgen, que suele recitarse por las órdenes contemplativas al margen del oficio obligatorio. La misma conciencia pudo haber impulsado al pintor a traducirla en la referencialidad de una naturaleza muerta, tan luminosa, si bien tomada en un cuarto interior, como para evocar un aura primaveral ("sicut dies verni"). La metáfora no es menos transparente en el cuadro que en el enunciado verbal.

\section{Un versiculo del profeta}

Si "circumdabant eam" es la clave de lectura ofrecida al exégeta, no hay que desdeñar otra posibilidad, ligada a un versículo bíblico y retomada con mucha frecuencia por la literatura alegórica mariana. Se basa sobre la interpretación convertida en usual del pasaje de Jer, 31, 22: "Creavit Dominus novum super terram: foemina circumdabit virum" ${ }^{\text {. }}$.

La aplicación a la concepción virginal de Cristo, presente en la Glossa ordinaria y en el repertorio de tipologías que es la Biblia mariana del pseudo-Alberto Magno ${ }^{61}$, es desarrollada así por Ricardo de San Lorenzo:

Gloriosum conceptum virginis absque laesione virginitatis describit Jeremias... Foemina id est virgo Maria, circumdabit gremio uteri sui... Virum id est Christum... Circumdabit, inquam, non aliunde, sed de se, quia de solum eius substantia sine semine viri sola operatione Spiritus sancti aedificatum est corpus Christi. Unde ipsa dicit Ecclesiastico XXIV 8: Gyrum caeli, id est qui claudit omnia, Circuivi

60 "Dios creó un hecho nuevo sobre la tierra: la mujer rodeará al hombre".

61 Aparece en la Opera omnia de san Alberto Magno, edizione Borget, vol. XXXVII, p. 414; "Maria immaculata circumdabit mirabiliter virum sine virili semine in gremio uteri sui. Ipsa est illud vas de quo dicit Spiritus sanctus: Vas admirabile opus Excelsi”. Sobre las obras marianas atribuidas a Alberto Magno, Albert Fries, Die unter dem Namen des Albertus Magnus überlieferten mariologischen Schriften. Literarkritische Untersuchungen, Münster W., Aschendorff, 1954 ("Beiträge zur Geschichte der Philosophie und Theologie des Mittelalters”, 37, 4). 
id est vestivi carne virginea; parvula puellula utero suo circumdabit hominem perfectum ${ }^{62}$.

Todo esto explicaría con "circumdabit" la disposición, pero no la presencia de rosas y lirios. El tema del útero virginal se encuentra con frecuencia asociado a temas florales en los comentarios al versículo I, 16 del Cantar, que suena "Lectulus noster floridus", donde "lectulus" representa el útero y "floridus" el hijo concebido. Uno entre los más difundidos de la época a la que se refiere el cuadro, el de Michele Ghisleri ${ }^{63}$, haciendo hablar a la virgen en primera persona, pone en su boca una evocación del lirio:

Ego quidem virginitate pulchra sum, pulchra pariter et partu, quia $\mathrm{tu}$, dilecte mi, et divinitate pulcher et humanitate decorus. Inde enim ingens illud in me factum est prodigium, quo lectulus uteri mei, in quo tu novem mensibus requievisti, per tui praesentiam redditus est floridus, duplici florens flore et re, nimirum quem concepi qui est flos campi et lilium convallium, et virginitate, cuius typus lilia sunt candidantia ${ }^{64}$.

Ghisleri dilata aquí un núcleo temático que reencuentro mucho más atrás en el comentario al Cantar de Ruperto de Deutz (siglo XII):

62 Jeremías describe la gloriosa concepción de la virgen sin merma de la virginidad... Foemina, es decir, la virgen María, rodeará con el vientre de su útero... Virum, es decir, Cristo... Circumdabit digo, no de otro modo sino de sí misma, porque el cuerpo de Cristo ha sido compuesto solo de su sustancia, sin semen del hombre, por intervención del Espíritu Santo. Por ello dice el Eclesiástico XXIV 8: Gyrum caeli es decir, aquel que reúne en sí el todo, Circuivi sola (lo he rodeado yo sola), es decir, lo he vestido de carne virginal; una muchacha pequeñita rodeó con su útero un hombre adulto" (De laudibus, 1. 4, c. 13, par. I).

63 Commentarii in Canticum canticorum, Venetiis, apud Ioannem Baptistam Ciottum et socios, 1617, p. 236 (1. I, v. 16, expositio 4).

64 "Yo soy bella a causa de la virginidad, bella igualmente a causa del parto, porque tú, oh mi dilecto, eres bello por la divinidad y espléndido por la humanidad. De ahí que se haya hecho en mí ese gran prodigio, por el cual el lecho de mi útero, en el cual has reposado nueve meses, con tu presencia se ha vuelto florido, floreciendo doblemente en la flor y en el hecho, es decir, en aquel que he concebido, que es la flor de los campos y el lirio de los valles, y en la virginidad, cuyo figurante son los cándidos lirios”. 
Lectulus, inquam id est uterus meus in quo tu quievisti totis novem mensibus et, salvo virginitatis meae sigillo, egressus est flos pulcherrimus ${ }^{65}$.

Este modo metafórico de representar la generación virginal de Cristo por medio de términos florales se había afirmado en textos donde el tono elocuente o la inspiración lírica prevalecen sobre la exposición racional, hasta el punto de hacer aceptables enunciados incoherentes si los tomamos al pie de la letra, en nombre de la coherencia que liga los figurantes subyacentes. Antiguo es el testimonio de un sermón mal atribuido a san Epifanio: "Virgo est lilium immaculatum quae rosam immarcescibilem genuit Christum”. El concepto se encuentra con frecuencia en los himnos: 1) "Virgo parit filium... Sicut rosa lilium"; o bien 2) "Gaude Virgo gratiosa, verbum verbo concepisti... Gaude fluens delicias, nunc rosa iuncta lilio"; o bien, 3) "Res nova mirabilis Rosa fragrat lilium Ignara viri seminis Virgo profert filium"; o incluso, 4) "Virgo flore redimitur, Rosa parit lilium". En el himno por la visitación de María e Isabel, encintas de Jesús y de Juan, 5) "In rosa latet lilium Et in antiqua flosculus"66. Las curiosas expresiones nacen porque se ha extendido a las especies privilegiadas del lirio y de la rosa, flores por excelencia, el enunciado "flor de flores", usado como fruto de una especulación que se dilata hasta el infinito en torno a la bíblica "radix Iesse" 67.

65 "El lecho es mi útero en el cual has reposado nueve meses, y, dejando intacto el sello de mi virginidad, ha salido la bellísima flor". En la edición al cuidado de Habranus Haacke, Turnhoult, Brepols, 1974, p. 35 ("Corpus christianorum Continuatio mediaevalis", 26).

66 El pasaje del sermón de san Epifanio, titulado De laudibus sanctae Mariae deiparae, se lee en PG 43, col. 495. Las otras citas son entresacadas en el siguiente orden: I. Mone, vol. II, 71, n. 377; Blume-Drevers, vol. XX, p. 184, n. 244; 2. G. G. Meerseman, Der Hymnos Akathistos im Abendland, vol. II, p. 212; 3. Mone, vol. II, p. 56, n. 364; Blume-Dreves, vol. LIV, p. 382, n. 244; 4. Mone, vol. II, p. 38, n. 348; BlumeDreves, vol. LIV, p. 382, n. 244; 4. Mone, vol. II, p. 38, n. 348; Blume-Dreves, vol. XLIX, p. 46, n. 67; Mone, vol. II, p. 114, n. 404; Blume-Dreves, vol. LII, n. 45.

67 Véase la impresionante cadena de citas de los Padres a los contemporáneos que Hipólito Marracci ha reunido a pie de página en el Mariale de Adamo di Perseigne, reutilizado en PL 211, col. 754, con una continuación para los símbolos colaterales de "virga Moysi" y "virga Aaron". 
Dice Ricardo de San Lorenzo: "Congruum erat florem cum flore concipi

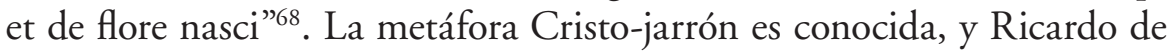
San Lorenzo la evoca justo en relación al versículo de Jeremías:

Vas admirabile Christus homo vel corpus Christi, opus excelsi id est Dei Trinitatis. Mirabile, nam contentum maius continente. Quid enim mirabilius quam lux divinitatis in testa humanitatis? nam mulier circumdabit virum ${ }^{69}$.

Retomando desde el principio los pasajes hasta ahora ilustrados, reconstituimos, eslabón tras eslabón, la siguiente cadena: de la ecuación "virgo et vir-flores" se hace derivar la de "virgo lilium-vir rosa" (o viceversa, para designar a María y a Cristo); de "mulier circumdabit virum", se hace derivar "lilium circumdabit rosam", sobre el modelo de "lilium generat rosam" que significa "virgo generat filium". Una vez encajadas una pieza con la otra, se reconstruye un mensaje orgánico. Es un mensaje sofisticado y a la vez cándidamente fluido el que se refiere al responsorio. Darle la preferencia supondrá acentuar en el cuadro los aspectos de refinamiento excéntrico, probablemente más aparente a nuestros ojos que a los de cualquier observador de su época. Entre la singularidad de una cavilación teológica y la de una rara, pero no intrincada iniciativa devota, ¿cuál preferir? La presencia de un texto bien hecho y bien conocido hace más plausible la segunda. La hipótesis más simple debería ser la más aceptada, hasta que los documentos no descubran otra verdad. Pero es cuestión de gustos. Y puesto que de los míos non est disputandum, que decida el cándido lector.

\section{Las formas del mensaje icónico}

Pasamos de los contenidos vehiculados a las formas que los vehiculan. En la época en la que el cuadro fue realizado, cuatro modos estaban en boga para transmitir mensajes con medios icónicos: el emblema, la empresa, el jeroglífico, el enigma. Los dos primeros son medios de comunicación

68 De laudibus..., 1. 12, c. 4. par. 10.

69 "Jarrón admirable es Cristo hombre o el cuerpo de Cristo, obra del excelso, es decir, de Dios trino. Admirable, porque el contenido es mayor que el continente. ¿Qué hay más maravilloso que la luz de la divinidad en el barro de la humanidad? De hecho la mujer rodeará al hombre" (Ibidem, 1. 10, c. 31, par. 22). 
mixtos de dibujo y palabra. Se discute si la parte verbal pertenece a la esencia del uno o de la otra, o solo a su perfección, pero en la práctica se admite la necesidad del epigrama o del mote. La falta en nuestro cuadro de una parte escrita, aparece ya desde el origen y no causada por la pérdida de un letrero de acompañamiento, podría excusarme de discutir si un conjunto de elementos florales concebido de esa forma puede constituir un cuerpo de empresa o una tabla de emblema. Indudablemente el lienzo ofrece materia para un emblema tanto en la hipótesis del responsorio como en la del versículo de Jeremías: un título sintético, un epigrama explicativo se les podrían añadir ágilmente. Pero en su forma presente con seguridad no es un emblema. No veo en cambio cómo pueda prestarse tal como lo vemos a la empresa - al menos a una perfecta empresa-, en tanto que el cuadro es el correlato de la frase completa ya del responsorio, ya del versículo bíblico, mientras que los cuerpos deberían concurrir solo parcialmente ${ }^{70}$. En cambio hay que considerar las dos técnicas del enigma y del jeroglífico. Jeroglífico es un ideograma que representa un significado lingüístico (por ejemplo luna-noche, mientras símbolo es más bien la ecuación luna-inestabilidad). Enigma (rebus) es un ideograma que representa el significado lingüístico ${ }^{71}$. En la interpretación que desciende del responsorio, rosa, lirio y disposición en corona son rebus que traducen "circumdabant flores rosarum et lilia convallium", el jarrón de rosas negro representa por el contrario un triple jeroglífico mariano. En el caso del versículo de Jeremías, las guirnaldas son jeroglífico por “foemina”, el ramo de rosas por "virum", mientras la disposición de las guirnaldas transcribe "circumdabit" a modo de rebus. Falta sin embargo en el uno y en el otro caso, pero visiblemente en el primero, la característica más refinada del rebus, la de formar palabras con dibujos que son representación de otras, como hizo, por ejemplo, quien transcribió la frase "morire mi farete" con el dibujo de dos moros, dos remos, la nota musical fa y una red. En su

70 Hablo de la empresa entendida en su sentido más riguroso, sobre cuyas prácticas infinitas giran las discusiones de los contemporáneos, como es sabido. He expuesto su funcionamiento en "Lettura delle imprese", en IV Centenario dell'Accademia della Crusca. La Crusca nella tradizione letteraria e lingüistica italiana, Firenze, 1985, pp. 41-63.

71 Así explico su acepción, entre las infinitas y disputadas hoy recurrentes, en Poesia per gioco, Bologna, Il Mulino, 1984, pp. 75-91. 
forma no enigmática, la de transcribir palabra a palabra con el dibujo respectivo, el rebus se usaba para ilustrar proverbios y dichos sentenciosos, que podían ser leídos también por los más simples (recuérdense Della Bella y Mitelli). De ese tipo es en el ámbito devocional una antífona. El pintor habría podido representar con la técnica del rebus también "eam-María”, trazando su silueta o transcribiendo su monograma; optó en cambio por el jeroglífico; rehusó así la solución iconográfica directa del cuadrito devoto en favor de las apariencias naturalistas de una naturaleza muerta arcanamente simbólica. Hizo que se encontraran dos lenguajes al reproducir los objetos en su aspecto natural, pero articulando su posición de modo que les confirió el poder de transcribir un mensaje verbal ya conocido. De esta invención deriva el encanto que el cuadro conserva también después la solución del enigma.

\section{Una oración en imagen}

Su destino práctico es difícil de precisar, más aún si hay que juzgarlo como documento aislado, que no forma parte de un complejo.

Emblemas, jeroglíficos, empresas, rebus de tema religioso responden a los dos tipos de discurso de tema metafórico codificados por la retórica sacra, y estaban puestos al servicio de dos ejercicios de piedad distintos, que asumían respectivamente aquellas formas discursivas.

El primer tipo es el de la alocución en torno a un solo sujeto metafórico. Además de en la predicación, se adoptaba ampliamente en la oración mental. Desde cuando se hizo ejercicio definido, la meditación necesitaba de medidas que tuviesen ocupado al orante por largo tiempo. Servía admirablemente a este fin el hacerle recorrer las partes de una entidad natural o las clases de sus propiedades, invistiéndolas de sentidos traslaticios. Los ejemplos se recogen por cientos en el mar inmenso e inexplorado de la literatura edificante que conduce a orar y meditar. Bersuire ${ }^{72}$ desarrolla la argumentación según el criterio de la morfología del figurante cuando representa en las espinas de la rosa el nacimiento de estirpe hebrea de la virgen, en las hojas hirsutas la penitencia, en los pétalos la caridad y la castidad, en los estambres el parto divino. Lo mismo hace con el lirio el

72 Reductorium morale super totam Bibliam, Venetiis, apud haeredem Hieronymi Scoti, 1583, 1. 12, c. 133, par. 4. 
interpolador de la Vitis mystica, 19-32, de san Buenaventura ${ }^{73}$, describiendo la virtud de Cristo en la raíz blanca, lucida, tierna, en el tallo robusto, alto, en las hojas, en los pétalos, en los estambres. También san Antonino de Florencia $^{74}$ señala "tria in lilio: in stipite viredinem, in flore albedinem, in semine fulvedinem" para significar incorrupción, pureza y santidad. Toma como referencia el criterio atributivo Pedro Comestor cuando asigna a la flor una héptuple propiedad: "quia tenuis, tener, lenis, pulcher, levis, fragrans, utilis"; Ricardo de San Lorenzo, que lo asume como modelo ${ }^{75}$, no tiene dificultad para elevarlas a dieciocho, y nada impide ir más allá, con tal de que no falte el puntillo del sofista y una aguda aplicación de los "loci comunes", como enseña Tesauro justo a propósito de la rosa ${ }^{76}$. La técnica es la de la metáfora continuada (por la cual el núcleo semántico "rosa" genera una serie de metáforas afines), o de la metáfora hilada (por la cual metáforas con motivaciones diversas se unen en un todo sintácticamente organizado).

Sobre la vertiente figurativa servían para este objeto los emblemas devotos, los jeroglíficos sacros y las tablas enigmáticas, que secundaban el trabajo de la imaginativa ocupada en reconstruir circunstancias, lugares, personas en el tiempo prolongado de un "morari cum Domino". La equivalencia con las características del discurso verbal argumentativo se realizaba por el dibujo con la inscripción en el cuerpo mismo del figurante o en las adyacentes escenitas secundarias (si no incluso en las didascalias), o bien en la representación de la flor en varias formas o posiciones, que sugerían al orante los figurados que debían ser evocados. Van der Sandt en el citado Mariae flos sitúa a la cabeza de cada discurso la imagen de una flor en cuyo corazón o pétalos son representados los misterios marianos que conecta; la viñeta sintetiza los datos que serán desarrollados en la argumentación. Análogamente David, con las tablas enigmáticas de su

73 Está entre los trozos espurios interpolados al tratado, editados en la Opera omnia, vol. VIII, pp. 196-216.

74 Summa theologica, 4, 4, 6, 6.

75 De laudibus..., 1. 12, c. 4, par. 8. La argumentación aducida por Ricardo como de Pietro Comestore también consta en el breve tratado De comparatione Christi ad florem, que aparece bajo el nombre de Ricardo de San Víctor en PL 196, col. 1031-32, y que se atribuye también a Hugo en Miscellanea (PL 177, col. 826-27).

76 Il cannocchiale aristotelico, p. 577. 
Pancarpium, ilustra las acciones en honor de María que el devoto realiza en correspondencia de los diversos símbolos.

El segundo tipo de discurso es el que en un solo enunciado lingüístico afirma una sola verdad divina. En la práctica piadosa servía a otro tipo de oración, llamada expirativa, que cerraba una invocación, una jaculatoria, un pío pensamiento en el tiempo brevísimo de un dicho.

También tenía esa sus soportes icónicos. Si la visión de una flor, de un pájaro, de un espectáculo natural debía elevar el ánimo hacia Dios (como predicaban a lo largo y ancho los maestros de espíritu), tanto más serviría al artificio de una composición visual estructurada para este fin, y tanto más si sabía hacer florecer en la apertura del enigma la sorpresa, óptimo incentivo para los afectos. Tal era la empresa que obligaba en su mensaje dividido entre mirada y palabra a formular una piadosa intención (y por ello las empresas ocupaban las estampitas domésticas no menos que los grandes complejos decorativos); tal el rebus, equivalente de una oración escrita, y por ello texto para recitar.

Nuestra naturaleza muerta se diferencia de los modos usuales a través de los cuales ese fin era perseguido por la técnica elegida de la pintura al óleo sobre tela; menos por el resultado figurativo, tan alto cualitativamente, si se considera el nivel alcanzado en temas análogos de la pintura al fresco o al temple y de los estucos en las decoraciones de santuarios o capillas como en Hergiswald, en la Asunción de Colonia, en Santa María de las Gracias de Saronno y otros lugares ${ }^{77}$; y también por los grabados y a veces por las acuarelas en muchos canivets exquisitos. Puede darse que una factura así elegida oculte el deseo de un piadoso que encarga para una pared doméstica, a fin de poderlo incluso llevar a otro sitio, un fragmento de los estucos y escudos, llenos de símbolos marianos, que la piedad barroca venía prodigando en los edificios del culto público. Puede

77 Para el santuarito de Hergiswald en Suiza son analizadas las 323 empresas marianas de Grete Lesky, Die Sinnbilder der Marienkirche zu Hergiswald, en Geschichte und Beschreibung der Wallfahrtskirche Hergiswald, Luzern, Schill-Druck, 1964, pp. 101-176; para la Asunción de Colonia, Wilfried Hansmann, Die marianischen Sinnbilder in der Jesuitenkirche St. Mariae Himmelfahrt in Köln. Dokumentation und Beiträge zum Abschluss ihrer Wiederherstellung 1980, Düsseldorf, Schwann, 1982, pp. 223-47 ("Beiträge zu den Bau - und Kunstdenkmäler im Rheinland", 28); para Saronno, Paolo Maria Sevesi, Il santuario de Saronno, Milano, tip. San Giuseppe, 1926, pp. 133-38. Una reseña de empresas marianas en Grete Lesky, Barocke Embleme in Vorau und anderen Stiften Österreichs, Graz, 1963, pp. 131 ss. 
darse que él haya querido fijar en materias nobles la efímera belleza y el aliento de los aparatos que se consumaban en una fiesta de María. Pudo moverlo también una aspiración más secreta. Emblemas, empresas, rebus como las oraciones o las estrofitas hímnicas trascritas bajo los iconos de las capillas, bajo los retablos o al lado de cuadros votivos, o en las mismas estampitas, ocultan otro anhelo del alma devota: el de "semper orare", porque, fijados los mensajes en el dibujo o en la escritura, la invocación, transitoria cuando es recitada oralmente, se fija en un simbólico "numquam deficere". De ahí la costumbre de cierto extremismo devoto de llevar sobre la propia persona oraciones cosidas en la ropa o a modo de escapulario. Tenerlas ahí quería ser no un llamamiento a recitarlas, sino un sustituto perenne de actos forzosamente intermitentes. Puede suceder que el secreto pensamiento del piadoso que hizo el encargo no fuese muy distinto; como intuye Bergström con la claridad que le deriva de un ser distinto ("this impresses him, who like the present Writer, is only a poor Lutheran”). La antífona pintada venía a ser para el devoto un silente canto sin amén, análogo al celebrado por los santos en torno a María, reina del cielo.

\section{Addendum}

Claudie Balavoine, con aguda mirada de experta en alfabetos artificiosos (mirada mental), me hace observar que, si se traza una línea entre los cuatro lirios y el jarrón central, se obtiene una M. Mi ojo se sumaría a su solución con consenso más pleno si viera lirios o al menos rosas blancas en la punta central de la letra. La disposición de las flores reclama de modo más decidido el "circumdare" de la antífona, tal como yo lo veo. Pero la interpretación hay que señalarla. ¿Qué significado y destino escondería una intención icónica tan obvia en el producto (la sigla mariana se encuentra por doquier), tan excéntrica en los medios? ¿El que hizo el encargo habría simplemente proyectado una estampita de gran formato? ¿O bien podemos reconocerle la intención de hacer una figura como las ansiadas por Mombaer para la "salutatio membrorum"? (vid. supra). En cuanto a la naturaleza icónica del mensaje, jamás deberíamos calificarlo como enigma y jeroglífico, mucho menos como emblema o empresa. Sería una cifra escrita con rosas y lirios de factura naturalista en lugar de con los trazos normales. 